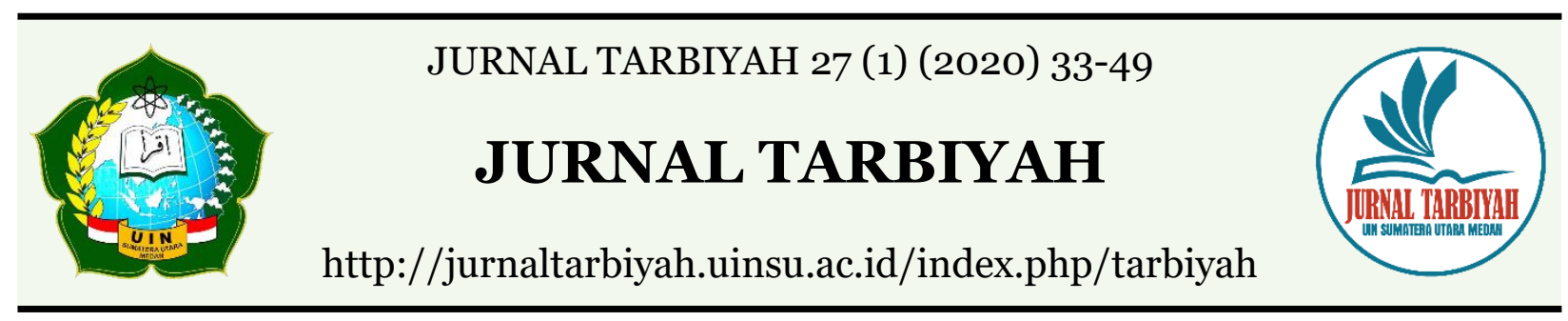

\title{
INNOVATION OF STUDENT CENTERED LEARNING MODEL BASED ON MICROBLOGGING EDMODO
}

\author{
Pirman Ginting1, Yenni Hasnah², Mutia Febriyana ${ }^{3}$ \\ 1,2,3Universitas Muhammadiyah Sumatera Utara, Medan, indonesia \\ Email : ${ }^{1}$ pirmanginting@umsu.ac.id, ${ }^{2}$ yennihasnah@umsu.ac.id, \\ 3 mutiafebriana@umsu.ac.id
}

DOI : 10.30829/tar.v27i1.673

Accepted: April 12th, 2020. Approved: June 25th, 2020. Published: June 30th, 2020

\begin{abstract}
This study aims to produce an innovative learning model based on Microblogging Edmodo. This research was conducted through the application of Research and Development (R\&D) methods which included several stages of research, it is started from designing SCL learning models based on microblogging edmodo, validation, and trials (small and large scale). The results of the study showed that the innovation of studentcentered learning models based on edmodo e-learning microblogging was feasible to be applied in the learning process. It can be seen from the validation reaches $79.16 \%$. The feasibility of the application is also strengthened by the increasing of the average percentage from audience validation. It results of $77.33 \%$ in small-scale trials and $91.30 \%$ in large-scale trials. This percentage shows that SCL learning models based on e-learning microblogging edmodo can be applied to students.
\end{abstract}

Keywords: innovation, SCL model, e-learning microblogging edmodo 


\section{INTRODUCTION}

The implementation of the curriculum in schools and universities require educators (lecturers) are more creative in teaching to increase the activity of students during the learning process. Innovative interactive learning models are crucial to produce quality learning. In other words, learning activities should be centered on the learner (Student Centered Learning) so that learning becomes more active and have an impact on increasing the motivation of learners. A good learning activity cannot be separated from the students' learning motivation, because it is very influential on their learning achievement. Therefore, the motivation of students in teaching and learning activities strongly supports the success of students to participate in learning, which has an impact on their learning achievement.

However, one of the problems is the low motivation to learn that affects their low learning achievement. Several factors include to the use of conventional process in teaching learning process and it create student's boredom. The learning process is centered on lecturers. Students are made as passive objects, meanwhile lecturers / instructors act as subjects who dominate learning activities. This learning models cannot be able to increase student participation in learning activities, either inside or outside classroom. This learning model decreases student mind and creativity. They tend to be passive. Whereas, they have a great opportunity to express ideas, interact and obtain feedback on the material. As a result, students are not motivate to participate in learning activities.

It cannot be denied that motivation is very important to create good learning. Learning motivation is a strong desire that grows from within students that serves as a driver in carrying out learning activities to achieve learning objectives. Dealing to this, Sardiman (2011) states that learning motivation is the overall driving force within students which leads to learning activities, ensures continuity of learning activities and a gives direction to learning activities in achieving of the goal. Based on the definition, it can be concluded that learning motivation is one of the factors which has a great role determines the smoothness of the learning process and student success.

In realizing of learning motivation, an educator (lecturer) has a very fundamental role by creating of an attractive and interactive learning design. Thus, it can foster student interest to participate in learning activities. The growth of student learning motivation can be observed from several indicators, it can be seen from the desires and activities of students in learning activities. Uno (2007) classifies indicators that affect learning 
motivation, which are as follows: (1) desires and ambition to succeed, (2) encouragement and needs in learning, (3) hopes and aspirations for the future, (4) appreciation and interesting activities in learning, and (5) a conducive learning environment. These indicators can be used as a reference in evaluating students' learning motivation. Furthermore, a strong learning motivation will lead to a good achievement. In this case, academic achievement can be interpreted as a student success in achieving the learning objectives which have been formulated before learning activities implemented. Indicators of success or achievement of participants can be measured through the tests that have been designed based on the indicators and learning objectives. Nikmah (2014), "learning achievement is the outcome or level of ability that has been achieved learners after participating in the learning process in a given time either to changes in behavior, skills and knowledge and then be measured and assessed later embodied in the figures or statements".

In an effort of increasing student achievement in learning, it needs several factors which support the learning process. Nikmah (2014) added there are two factors which influence on student achievement. They are internal and external factor. But, this study discusses external factor which is focused on the application of interactive learning model. It is based on student centered learning by using microblogging edmodo as an effort to increase student achievement and motivation. The implementation both of aspects can add creativity on students and teachers create an innovative and attractive teaching learning process.

Besides of motivation, the utilizing of technology as learning media is still lack. It also affects the low quality of learning. Then, these factors can reduce student interest in learning. In fact, most students already have these facilities, such as laptop and tablet. The students can use them to support efficient and interesting learning process. For example, overall students can access the internet network available on campus or their quota through the use of a laptop or gadget that they have. However, this opportunity cannot be fully utilized.

Therefore, the lecturers need a creative effort to innovate a learning model to increase student motivation and creativity in learning. in addition, the students also need an opportunity to participate in learning activities. The learning model must be able to emphasize student-centered learning, where students have more opportunities to interact with learning. Meanwhile, the lecturer roles as a facilitator and guide the students in teaching and learning activities. Student Centered Learning (SCL) gives freedom to 
students to have the opportunity and facilities. Student centered learning also lead the students to explore their own knowledge to deep their and improve their quality (Antika, 2014). It can be concluded that student centered learning can optimize the independence of student learning in exploring and developing knowledge more actively.

Student Centered Learning (SCL) is one of learning models have already in learning activities of education. This model gives freedom to the students in learning activities. The student can gain knowledge and enrich their knowledge in depth. This model can also build an independence and self-esteem. According to Harsono (2008), "Student centered Learning (SCL) is also a learning strategy places students as active and independent learners, as adult learners, they can be fully responsible for their learning and able to learn beyond the classroom. The students are expected to have and live a lifelong learner spirit and master hard skills and soft skills support one another through this model"

Now days, curriculum based KKNI recommends on the implementing SCL in the learning process because it has several advantages; (1) students will have their own belonging as a real participant; (2) students have strong motivation to participate in learning activities; (3) the growth of a democratic atmosphere in learning which creates vivid dialogue and discussion for mutual learning among students; (4) SCL can add insight into the mind and knowledge for lecturers or educators because of there are something experienced and conveyed by students may not have been known before delivered by the lecturer (Sudjana, 2005). This definition can conclude that the application of SCL in learning can increase motivation, creativity, and student learning independence in exploring and developing their knowledge.

Thus, the implementation of learning with the SCL model can create a unique learning atmosphere. The Directorate General of Higher Education of the National Education Ministry quoted by Hadi (2017) states that SCL learning is characterized by: a) Students can study either individually or group to build knowledge through seeking and exploring information and technology needed actively by their selves rather than being passive recipients, b) Lecturers play a role as FEE and guides on the sides rather than as mentors in the center, help students access information, organize and transfer find solutions to real everyday problems, rather than merely being a gatekeeper of information; c) Students are not only competent in their field of science, but also competent in learning. It means that students not only master their course material, but also learn the way (learn how to learn) through discovery, inquiry, problem solving and 
development occurs; d) Learning becomes a community activity facilitated by lecturers, who are able to manage their learning to be student-oriented; e) Learning is more understood as lifelong learning, a skill needed in getting of the job; and f) Learn to utilize available technology as a source of learning information and a tool for empowering students to achieve the full skills (intellectual, emotional, and psychomotor) needed.

In creating of active learning and maximizing of the result, the application of the SCL learning model is collaborated to online learning media edmodo microblogging. Edmodo is a social media Learning Management System that can be a special network for lecturers and students to share information in groups, such as giving online tests and sending articles among the lecturers and the students. Thus, learning activities can be held in anytime. From several research results revealed that the use of Edmodo Microblogging in learning activities has a very significant impact on motivation, activities and learning outcomes of students. Among of them, Rahmawati (2014) concluded that there were differences in motivation and learning achievement between Edmodo-based and non-Edmodo-based classes. Furthermore, Ginting \& Hasnah (2016) revealed that the use of Edmodo, student learning achievement has significantly increased with an average graduation rate of $95.24 \%$. In addition, student learning activities also improved with an average percentage of $89,29 \%$.

According to Zwang (2010), edmodo is education site based on social networking which provides various content for education. Teachers / lecturers can post learning materials, share links and videos, assignments, and notify student grades directly. Edmodo can store and share all digital content including blogs, links, images, videos, documents, and presentations. So, Edmodo is a social media connect teachers / lecturers with students in a group as a place the teacher / lecturer can send learning material, agenda, assignments and assess directly

If we compare to other social media Learning Management System, Edmodo has several advantages as follows: (1) Edmodo is similar to facebook, easy to use, (2) closed group collaboration, only those who has group code can attend classes, (3) edmodo is free, it can be accessed online, and available for smartphone, android and iphone devices, (4) edmodo does not require a server at school / campus, (5) edmodo can be accessed anywhere and anytime, (6) edmodo is always updated by the developer, (7) edmodo can be applied in one class, one school, between schools within a city or district, (8) edmodo can be used for students at school / university student, teachers / lecturers, and parents, (9) edmodo is used to communicate using social media models, learning materials, and 
evaluation, (10) edmodo supports the team teaching, co-teacher, and teacher models, (11) there is a notification, (12) feature "Badge" can be used to increase student motivation (Priowirjanto, 2013).

If we compare to other social media Learning Management System, Edmodo has several advantages as follows: (1) Edmodo is similar to Facebook, easy to use, (2) closed group collaboration, only those who has group code can attend classes, (3) Edmodo is free, it can be accessed online, and available for smartphone, android and iphone devices, (4) Edmodo does not require a server at school / campus, (5) edmodo can be accessed anywhere and anytime, (6) Edmodo is always updated by the developer, (7) Edmodo can be applied in one class, one school, between schools within a city or district, (8) Edmodo can be used for students at school / university student, teachers / lecturers, and parents, (9) Edmodo is used to communicate using social media models, learning materials, and evaluation, (10) Edmodo supports the team teaching, co-teacher, and teacher models, (11) there is a notification, (12) feature "Badge" can be used to increase student motivation (Priowirjanto, 2013).

Thus, the application of student centered learning based online learning microblogging Edmodo is expected to be solution in creating of active, innovative and efficient learning. Then, it can increase the activeness, motivation, and independence contributes to improve student learning achievement.

Based on the description above, this study was conducted to analyze the factors build student motivation in participating in English learning, designing of English learning through the Student Centered Learning model based on Edmodo Online Learning Microblogging, and how the implementation of learning models in the classroom.

This research is very useful in increasing student learning motivation through the application of interactive learning models based on student centered learning. Then, this learning model also makes students more creative and independent in implementing of the learning process. As addition, the use of Edmodo as a learning media, it can support the student centered learning model, makes learning English more efficient and optimal because learning activities are not limited to the classroom, but can be carried out anywhere and anytime. The teaching material is designed refers to the development of information and the needs of the job. Furthermore, the use of microblogging Edmodo brings students to utilize their technological facilities (gadgets, laptops, and internet) positively. 
This research is conducted by using Research and Development (R\&D) method focused on the application of the innovations of Student Centered Learning models based on elearning microblogging edmodo which includes several stages of research; the design of learning models, validations, and trials (small and large scale)

\section{RESULTS AND DISCUSSION}

In general, this learning innovation research is carried out through five stages, including planning the design of Student Centered Learning (SCL) based on e-learning microblogging edmodo, validation, trials, initial product field trials (small scale trials), and field trials main product (in class).

\section{Initial Draft of SCL Learning Model Based on Microblogging Edmodo}

Student centered learning model innovation is basically designed based on the characteristics of the learning model based on students (student centered learning), where students play a more active and participatory role in the learning process. Meanwhile, the lecturer (instructor) is expected to play the role of a facilitator, who able to accommodate the needs of students related to learning activities. This student centered learning model innovation is integrated with online learning media, namely microblogging edmono so that learning activities can continue in the outside of the classroom. But, the learning process can be monitored an controlled by the lecturers. In spite of them, the learning process also gives a space to the students and lecturerers, but also provide a space for every parents who monitor the learning progress. Microblogging Edmodo is an internet-based learning platform (e-learning) which can be accessed wherever and whenever. In addition, this learning platform also provides space not only for students and lecturers to carry out the learning process, but also provides space for parents to monitor the progress of their children's learning activities. Another advantage from Microblogging Edmodo is that it can be used in groups. Therefore, learning collaboration as one of the characteristics of the student centered learning model can still be implemented optimally.

The initial design of the SCL model based on Microblogging Edmodo was compiled based on the results of the research team discussions and input from the experts, lecturers and teachers in the field of English education studies. Following is the initial draft of the SCL learning model based on Edmodo Microblogging:

a. Making groups. Making of group members involves all students by counting in turns limited to the number of groups needed. For example, the number of groups 
needed is eight groups, so students simply count to eight. After that, students count again from the number one and so on until all students have mentioned the numbers. Furthermore, students who mention the same numbers will join one group. Every students who say the same number will join in a group.

b. Determination of the topic of discussion. Each group is given the same topic. The duration of group discussion depends on the level of difficulty of the material (1520 minutes recommended).

c. Stages the implementation of the discussion and target achievements. Each group is given 15-20 minutes (depending on the level of difficulty of the material) to discuss in their groups about the given topic, adjusted to the target / goal

d. Two or three students from each group go to visit the other groups and gather as much information as possible. Meanwhile, the other two stayed in their groups to serve and share information about the results to students who visits their groups. In this case, the lecturer must determine the overall duration of the visiting and set a time limit for visits to each group.

e. Two or three students from each group go to visit the other groups and gather as much information as possible. Meanwhile, the other two stayed in their groups to serve and share information about the results to students who visits their groups. In this case, the lecturer must determine the overall duration of the visiting and set a time limit for visits to each group.

f. Next, every student who visits another group is asked to return to their groups.

g. Each group crosschecks the information obtained to the results of their own group discussions, and finalizes the discussion information.

h. Each group crosschecks the information obtained to the results of their own group discussions, and finalizes the discussion information.

i. Randomly, the lecturer points each group to deliver the final answer orally. Meanwhile, other group members are listening and responding if they finds the different information or unsatisfactory answers

j. Lecturers and students conclude the material

k. Next, the lecturer posts the topic (assignment) on the Edmodo and asks each group to complete and finish the assignment online.

1. Students from other groups are welcome to submit responses toward the answers or give questions if there are unclear answers or statements. Note: each group member who gets the assignment is responsible for his group. In addition, students 
from other groups also have the opportunity to help, if another group find the problem. Lecturers need to manage the period of discussion so that each group member can actively participate at the same time.

m. Lecturrer concludes the learning material

\section{Validation}

A temporary draft of the SCL learning model based on Microblogging Edmodo was validated by experts before the trial. This research involved one expert from lecturer and one professional teacher as validator. Validation is carried out by a team of validator (lecturers and teachers) by providing responses to the evaluation sheets and the initial draft of SCL learning model based on microblogging Edmodo. Evaluation data obtained from experts and it is used as a reference for conducting a draft test of learning models. The results of validation are presented in the table below.

Table 1 Validation of SCL berbasis E-Learning Microblogging Edmodo

\begin{tabular}{|c|c|c|}
\hline \multirow{2}{*}{ Rubric Assessment } & \multicolumn{2}{|c|}{ Validator } \\
\hline & $\mathbf{I}$ & II \\
\hline Learning theory about Student Centered Learning (SCL) is stated clearly & 3 & 4 \\
\hline $\begin{array}{l}\text { Theory or concept of teaching media "Microblogging Edmodo is stated } \\
\text { clearly }\end{array}$ & 4 & 3 \\
\hline Background of developing learning models is clearly stated. & 2 & 3 \\
\hline The goal of developing learning models is stated clearly & 3 & 4 \\
\hline The description of learning model is stated clearly & 4 & 4 \\
\hline The system of learning model is stated clearly & 3 & 3 \\
\hline The system of learning social model is stated clearly & 3 & 3 \\
\hline The learning system support is clearly state clearly & 2 & 3 \\
\hline Use of learning approach is stated clearly. & 4 & 4 \\
\hline Steps in learning are stated clearly & 3 & 4 \\
\hline Evaluation and assessment are stated clearly & 2 & 2 \\
\hline Learning outcome is stated clearly & 3 & 3 \\
\hline Total & 36 & 40 \\
\hline Average & \multicolumn{2}{|c|}{36,5} \\
\hline Percentage & \multicolumn{2}{|c|}{$79,16 \%$} \\
\hline Validator & \multicolumn{2}{|c|}{ Valid } \\
\hline
\end{tabular}


Based on the validation above, it can be stated that the innovation model of Student Centered Learning (SCL) based on E-Learning Microblogging Edmodo has been stated as good and it can be applied in learning activities. Eventhough, it still needs revision in several sections. They are on the background of developing learning models, support systems for learning models, evaluation and assessment. The validation score is obtained for the three items is 2 and it is declared not valid. Therefore, it is necessary to revise explanation more comprehensive about the background of learning model innovation, a support system for implementing learning models such as internet availability and an assessment system for learning outcomes towards the application of the learning model being designed. Suggestions from the validator became a reference in making revisions to the feasibility of the learning model design.

\section{An analysis of trial in small scale}

After the SCL learning model based on Edmodo Microblogging was validated, a trial was carried out to students with small scale classes consists 14 students. This trial aimed to measure the level of feasibility and evaluate the weaknesses and effectiveness of the learning model. Furthermore, the results of this trial are evaluated and the results are used as a basis for revising the quality of the product before field trials are conducted. The results of trials conducted on a small scale can be seen in the following table.

Table 2 Questionnaire Results from Student Response (Audience Validation)

\begin{tabular}{|l|c|}
\hline \multicolumn{1}{|c|}{ Statement } & Score \\
\hline Apperception, the explanation from the lecturer can attract & $78,33 \%$ \\
\hline conveying of motivation can rise sprite in learning & $80 \%$ \\
\hline Learning process can increase learning spirit and learning activity & $80 \%$ \\
\hline presenting of material is comprehended clearly & $78,33 \%$ \\
\hline presenting of example is matching to the material & $76,67 \%$ \\
\hline I am able to finish and do the exercise easily & $80 \%$ \\
\hline Lecturer often helps the students if they have difficulty in learning & $80 \%$ \\
\hline Times for discussion, presentation and activity are managed based & $81,67 \%$ \\
\hline on time allocation & $83,33 \%$ \\
\hline I would like to summarize learning material to memorize easily. & $78,33 \%$ \\
\hline In learning, I try hardly to comprehend the material & \\
\hline
\end{tabular}




\begin{tabular}{|l|c|}
\hline $\begin{array}{l}\text { The lecturer gives an occasion to the whole students to ask towards } \\
\text { learning material. }\end{array}$ & $80 \%$ \\
\hline Lecturer confirmed the correct opinion & $78,33 \%$ \\
\hline $\begin{array}{l}\text { Utilizing of edmodo gives an occasion to the students to study more } \\
\text { flexible }\end{array}$ & $61,67 \%$ \\
\hline Utilizing of edmodo gives an occasion to create cooperative learning & $63,33 \%$ \\
\hline $\begin{array}{l}\text { In the end session, lecturer guides student to take conclusion toward } \\
\text { learning material. }\end{array}$ & $80 \%$ \\
\hline \multicolumn{1}{|c|}{ average } & $\mathbf{7 7 , 3 3 \%}$ \\
\hline
\end{tabular}

The results of the percentage of student questionnaires indicates that the level of quality of the learning model products has been categorized "Good". It can be seen from the questionnaire responses of students who reached $77.33 \%$. Therefore, it can be applied in learning activities. However, it still needs revision, especially in the use of microblogging Edmodo as a medium of online learning to produce higher quality products. Product revisions made based on the results of evaluation of data in small-scale trials. From this, it is expected to produce a better product improvements and the application can run well in the next trials.

\section{Product Revision After Small Scale Trial}

From the results of the analysis on a small-scale trial, the product revision process is based on problems arise during the implementation of the trial and the advice of the experts. There are revisions has produced after the trial on a small scale include; (a) the division of students must be heterogeneous, (b) the duration of the time to visit other groups is shorter and (c) the role of students; each group member has the opportunity to become a resource person and go to other groups to gather information. In addition, the stages of applying the learning model also need to be clarified. Comparison of learning model products before and after revision is presented in the table below

Table 3 The Differences of Product before and after Revision

\begin{tabular}{|c|c|c|}
\hline $\begin{array}{c}\text { The aspects of } \\
\text { Revision }\end{array}$ & Before Revision & After Revision \\
\hline
\end{tabular}




\begin{tabular}{|c|c|c|}
\hline 1. grouping & $\begin{array}{l}\text { 1. members of group is } \\
\text { determined by the student }\end{array}$ & $\begin{array}{l}\text { 1. members of group is determined } \\
\text { by lecturer based on their level }\end{array}$ \\
\hline $\begin{array}{l}\text { 2. duration } \\
\text { visiting }\end{array}$ & $\begin{array}{l}\text { 2. three minutes for each } \\
\text { student }\end{array}$ & 2. five minutes for each students \\
\hline $\begin{array}{l}\text { 3. the role of } \\
\text { student }\end{array}$ & $\begin{array}{l}\text { 3. two students as speakers } \\
\text { and three students who } \\
\text { visit another group }\end{array}$ & $\begin{array}{l}\text { 3. each student has a role as a } \\
\text { speakers and also collect the } \\
\text { information from other group. }\end{array}$ \\
\hline
\end{tabular}

\section{Draft of Learning Model on a Large Scale}

The draft of learning model was designed after revision based on the results of reflection on small scale trials. At this stage, improvements were made to three important aspects, namely the division of students (groups), duration of visits, and the role of students. In terms of groping composition, lecturers divides group members based on the level of student's achievement. This way will form heterogeneous group. Meanwhile, the previous grouping was determined by the students themselves and this way tends to form homogeneous groups. In addition, each group member has the same role. Group members who previously served as spekers in their groups to share information with guest students and they also had the opportunity to visit other groups to obtain information. Similarly, members who act as guests in other groups before, they also get a role as speakers in their own group. It is intended that each student can participate actively in learning activities and they have the same opportunities in mastering the learning materia. The duration of each student's visit to another group was also extended into five minutes. The following is the procedure for applying student-centered learning model based on microblogging edmodo

a. Division of groups. In this case, the division of group involves all students by counting in turns limited to the number of groups needed. For example, the number of groups needed is eight groups, so students simply count to eight. After that, students count again from the number one and so on until all students have mentioned the numbers. Furthermore, students who mention the same numbers will join one group. Individuals who say the same number will join a group.

b. Determination of the topic. Each group is given the same topic to discuss (division of learning topics can be improvised according to learning needs). The duration of group discussion depends on the level of difficulty of the material (15-20 minutes recommended). 
c. Steps in conducting discussions and target of learning achievement. Each group is given 15-20 minutes (depending on the level of difficulty of the material) to discuss in their own groups about the topic, it should adjust to the target / goal to be achieved.

d. Two or three students from each group go to visit the other groups and gather as much information as possible. Meanwhile, the other two stayed in their own groups to serve and share information about their discussions with students who visiting their groups. In this case, the lecturer must limit the overall duration of the visit, and set a time limit for visits to each group.

e. After three students have finished visiting another group and returned to their own group, $2 / 3$ of the students who had previously acted as the speakers in the group were assigned to visit other groups that had not been visited before.

f. Then, every students who visits other group were asked to return to their own group

g. Every members of group explains some information gained to the other group

h. Every group summarizes the material based on thier discussion and information that they have gained from another group

i. Randomly, the lecturer asks the group to deliver their final answer orally. Meanwhile, the other group members are asked to listen and respond towards the the different and unsatisfy information or answer

j. Lecturer and students make conclusion together

k. Furthermore, lecturer gives assignments to students through the Edmodo as a follow-up , develop and measure students' understanding of the learning that has been given. Next, lecturer asks to group to complete / work on assignments online randomly.

1. The other group analyzes the results of the group's work and gives feedback on the answers. Note: each group member who gets the assignment is responsible for the group. In addition, students from other groups also have the opportunity to assist if the other group gets into trouble. Lecturers need to manage the period of discussion so that each group member can actively participate at the same time.

m. Lecturer concludes learning material

Here are some displays of wallmicroblogging Edmodo on learning activities. 


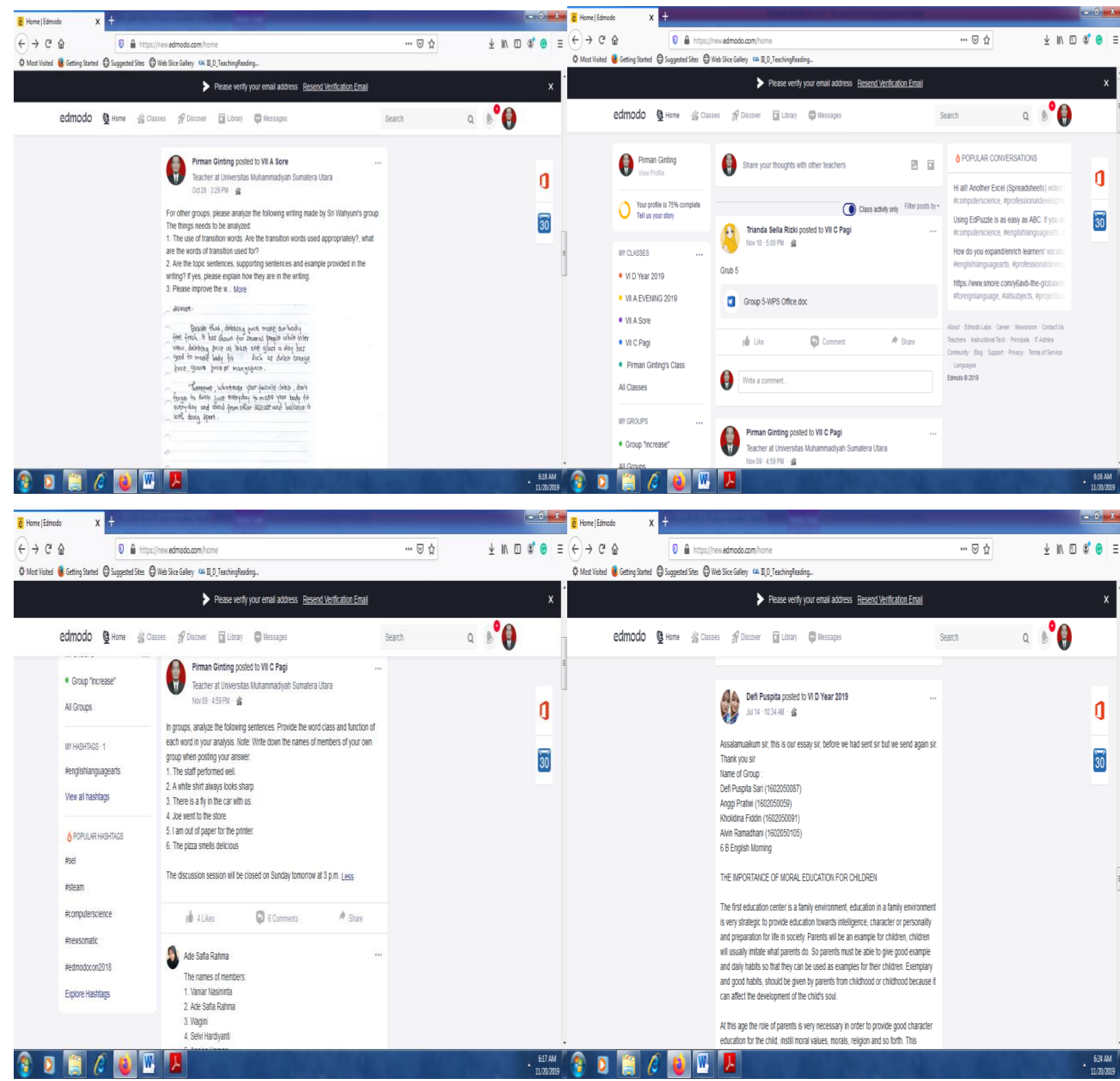

Figure 1: displays of wallmicroblogging Edmodo on learning activities.

\section{Product Revision of Large Scale Trial}

A large-scale trial was conducted in a class of 32 students. After conducting trials on a large scale, a revision of the product was carried out to ensure the feasibility of applying the learning model. Product revision is conducted absed on the expert. The experts' recommends that the learning model can be continued. The learning model is feasible and applicable in learning activity.

\section{Analysis of large scale trial}

After the SCL learning model based on Microblogging Edmodo was validated, a trial was carried out to students with small scale classes around 14 students, then 
continued into large-scale trials. This trial aims to measure the level of feasibility and evaluate the weaknesses and effectiveness of the learning model. Furthermore, the results of this trial are evaluated and the results are used as a basic for revising the quality of the product prior to field trials. The results of large scale trial can be seen in the following table.

Table 4 The Result of Validation Audience

\begin{tabular}{|l|c|}
\hline \multicolumn{1}{|c|}{ Statement } & \multicolumn{1}{|c|}{ Score } \\
\hline Apperception, lecturer's presentation can attract attention & $97,66 \%$ \\
\hline The motivation is delivered to rise learning spirite & $89,06 \%$ \\
\hline Learning process increases learning spirit and activity & $90,62 \%$ \\
\hline The material presented is clearly understood. & $89,06 \%$ \\
\hline Presenting of example is matching to the material & $89,06 \%$ \\
\hline I am able to finish and do the exercise easily & $88,28 \%$ \\
\hline Lecturer often helps the students if they have difficulty in learning & $91,40 \%$ \\
\hline $\begin{array}{l}\text { Times for discussion, presentation and activity are managed based on } \\
\text { time allocation }\end{array}$ & $94,53 \%$ \\
\hline I would like to summarize learning material to memorize easily. & $94,53 \%$ \\
\hline In learning, I try hardly to comprehend the material & $93,75 \%$ \\
\hline $\begin{array}{l}\text { The lecturer gives an occasion to the whole students to ask towards } \\
\text { learning material. }\end{array}$ & $89,84 \%$ \\
\hline Lecturer confirmed the correct opinion & $88,28 \%$ \\
\hline $\begin{array}{l}\text { Utilizing of edmodo gives an occasion to the students to study more } \\
\text { flexible }\end{array}$ & $90,62 \%$ \\
\hline Utilizing of edmodo gives an occasion to create cooperative learning & $87,50 \%$ \\
\hline $\begin{array}{l}\text { In the end session, lecturer guides student to take conclusion toward } \\
\text { learning material. }\end{array}$ & $95,31 \%$ \\
\hline \multicolumn{1}{|c|}{ Average } & $\mathbf{9 1 , 3 0 \%}$ \\
\hline
\end{tabular}

From the table above, it can be seen that the level of product validation reaches 91.30\%. Therefore, the SCL learning model based on Microblogging Edmodo has met the criteria very good. It is meant that the learning model is usable in learning. This finding takes from the success of student centered learning innovation based on e-learning microblogging Edomodo which has been accepted and followed by students. From the results of trials and questionnaires has been conducted on a small and large scale, the 
application of the SCL learning model based on e-learning microblogging edmodo can be followed by students well. Thus, the SCL learning model based on Microblogging Edmodo is usable in learning activities.

There are several advantages of applying the student centered learning model based on e-learning microblogging edmodo, such as: (a) students become more active participate in the learning process. Because of each student has the opportunity visit to another group to obtain information and at the same time as a speaker (resource) in their own group in presentation. (b) Learning becomes more interactive and fun. (c) it can be applied to all classes. (d) Students are more confident in expressing their opinions. (e) Learning can be carried out anywhere and anytime through the use of smart phone technology. (f) the better in utilization of smart phone technology.

In spite of strengthness, the researchers also realize that this innovation also has weaknesses. It include to the difficulties in classroom management, need more time in preparing material, media and personnel, and the need for internet access in running edmodo.

\section{CLOSING}

Based on the research results, it can be concluded that the innovation products of student centered learning models based on e-learning Microblogging Edmodo are feasible to be applied in the learning process. It can be seen from the results of the analysis of the experts. The percentage can reach into $79.16 \%$. The feasibility of the application is also supported by increasing of percentage from audience validation result into $77.33 \%$ in small-scale trials and $91.30 \%$ in large-scale trials. This percentage shows that the application od SCL learning products based on E-Learning Microblogging Edmodo can be used and followed by students.

The results of this study also gives meaning that the student centered learning model based on e-learning Mcroblogging Edmodo can be used as an alternative learning model in learning activities. Thus, the researchers expect that an effort is really needed to increase student activity and achievement in the learning process. 


\section{REFERENCES}

Antika, R. R. (2014). Proses Pembelajaran Berbasis Student Centered Learning (Studi Deskriptif di Sekolah Menengah Pertama Islam Baitul 'Izzah, Nganjuk).Jurnal BioKultur, Vol.3, (1),251-263.

Ginting, P \& Hasnah, Y. (2015).Penerapan Model Students Centered Learning (SCL) Melalui Student Teams-Achievement Divisions Untuk Meningkatkan Kemampuan Menulis (Writing Skill) Mahasiswa Bahasa Inggris Fkip Umsu Dalam Karya Tulis Ilmiah (Scientific Writing).Laporan Akhir Teaching Grant(unpublihsed).Medan: LPPM UMSU.

Hadi, R. (2007). Jurnal Pemikiran Alternatif Pendidikan: Dari Teacher-Centered Learning ke Student-Centereded Learning: Perubahan Metode Pembelajaran di Perguruan Tinggi.INSANIA|Vol. 12|No. 3| Sep-Des 2007|408-419

Harsono, (2008).Student-Centered Learning di Perguruan Tinggi.Jurnal Pendidikan Kedokteran dan Profesi Kesehatan Indonesia. Yogyakarta: Fakultas Kedokteran Universitas Gadjah Mada.Vol. 3 (1) Maret 2008

Nikmah, A. (2014). Dampak Penggunaan Hand Phone Terhadap Prestasi Siswa. Vol. 5 No. 1. ISSN: $2337-3253$.

Priowirjanto, G. (2013). Southeast Asian Ministers of Education Organization Regional Open Learning Centre.

Rahmawati, A. U. (2014). Efektivitas Penerapan Edmodo Terhadap Pembelajaran Kimia Kelas XI SMAN 1 Wates Tahun Ajaran 2013/2014. E-journal UNY Pend. Kimia - S1, Vol.III, (7) 2014.

Sardiman. (2011). Interaksi dan Motivasi Belajar Mengajar. Jakarta: Rajawali Pers.

Sudjana, D. (2005). Metoda dan Teknik Pembelajaran Partisipatif. Bandung: Falah Production.

Uno, H. B. (2007). Teori Motivasi dan Pengukurannya. Jakarta: Bumi Aksara. Zwang, J. (2010). Edmodo: A free, secure social networking site for schools. http://www.eschoolnews.com/2010/12/15/edmodo-a-free-secure-socialnetworking-site-for-schools/, diakses 15 Juni 2017. 